\title{
GEOGRAPHIC ASSIGNMENT OF SEABIRDS TO THEIR ORIGIN: COMBINING MORPHOLOGIC, GENETIC, AND BIOGEOCHEMICAL ANALYSES
}

\author{
Elena Gómez-Díaz ${ }^{1,2,3}$ and JaCoB GonZÁlez-Solís ${ }^{1}$ \\ ${ }^{1}$ Department Biologia Animal (Vertebrats), Av. Diagonal 645, Barcelona 08028, Spain \\ ${ }^{2}$ Institut de Recerca Oncologica, Hospital Duran i Reynals, Gran Via km 2.7, 08907 L'Hospitalet, Barcelona, Spain
}

\begin{abstract}
Longline fisheries, oil spills, and offshore wind farms are some of the major threats increasing seabird mortality at sea, but the impact of these threats on specific populations has been difficult to determine so far. We tested the use of molecular markers, morphometric measures, and stable isotope $\left(\delta^{15} \mathrm{~N}\right.$ and $\left.\delta^{13} \mathrm{C}\right)$ and trace element concentrations in the first primary feather (grown at the end of the breeding period) to assign the geographic origin of Calonectris shearwaters. Overall, we sampled birds from three taxa: 13 Mediterranean Cory's Shearwater (Calonectris diomedea diomedea) breeding sites, 10 Atlantic Cory's Shearwater (Calonectris diomedea borealis) breeding sites, and one Cape Verde Shearwater (C. edwardsii) breeding site. Assignment rates were investigated at three spatial scales: breeding colony, breeding archipelago, and taxa levels. Genetic analyses based on the mitochondrial control region (198 birds from 21 breeding colonies) correctly assigned 100\% of birds to the three main taxa but failed in detecting geographic structuring at lower scales. Discriminant analyses based on trace elements composition achieved the best rate of correct assignment to colony $(77.5 \%)$. Body measurements or stable isotopes mainly succeeded in assigning individuals among taxa (87.9\% and $89.9 \%$, respectively) but failed at the colony level (27.1\% and $38.0 \%$, respectively). Combining all three approaches (morphometrics, isotopes, and trace elements on 186 birds from 15 breeding colonies) substantially improved correct classifications $(86.0 \%, 90.7 \%$, and $100 \%$ among colonies, archipelagos, and taxa, respectively). Validations using two independent data sets and jackknife cross-validation confirmed the robustness of the combined approach in the colony assignment $(62.5 \%, 58.8 \%$, and $69.8 \%$ for each validation test, respectively). A preliminary application of the discriminant model based on stable isotope $\delta^{15} \mathrm{~N}$ and $\delta^{13} \mathrm{C}$ values and trace elements (219 birds from 17 breeding sites) showed that 41 Cory's Shearwaters caught by western Mediterranean long-liners came mainly from breeding colonies in Menorca (48.8\%), Ibiza (14.6\%), and Crete (31.7\%). Our findings show that combining analyses of trace elements and stable isotopes on feathers can achieve high rates of correct geographic assignment of birds in the marine environment, opening new prospects for the study of seabird mortality at sea.
\end{abstract}

Key words: assignment methods; biogeochemical markers; bird mortality at sea; Calonectris spp.; longline fisheries; mitochrondrial DNA; shearwaters; spatial structure.

\section{INTRODUCTION}

Interactions between seabirds and anthropogenic activities frequently result in the death of many individuals. Threats posed by human activities at sea, such as long-lining, offshore wind farms, and oil spills, have increased dramatically over the last decades. Globally, long-lining is one of the world's most serious threats for pelagic seabirds (Lewison et al. 2005). Seabird interactions with longline fisheries often results in the accidental mortality of many seabirds that are hooked when stealing baits (Brothers et al. 1999). Besides, recent major oil spills have been directly responsible for the deaths of several hundred thousands of birds (Cadiou et al. 2003, Carter 2003, García et al.

Manuscript received 19 July 2006; revised 1 November 2006; accepted 29 January 2007. Corresponding Editor: R. L. Knight.

3E-mail: elegomez@ub.edu
2003). In addition, the construction of wind facilities offshore may become Europe's most extensive technical development in marine habitats, but relevant data on the impact on seabirds are only just starting to become available (Garthe and Hüppop 2004, Hüppop et al. 2006).

Since seabirds are particularly vulnerable to any factor increasing adult mortality, chronic and accidental impacts of human activities at sea can jeopardize the viability of populations (Lebreton and Clobert 1991). Although conservation concerns have mainly focused on the impact of threats at the breeding colonies (Boersma et al. 2002), the exposure of mixing populations to the same threats in specific wintering areas can compromise the viability of multiple populations (González-Solís et al. 2007). Thus, understanding the impact of seabird mortality at sea requires not only quantifying the number of seabirds killed, but also determining their 
origin. Ultimately, knowing the provenance will allow reassessment of the threats faced at sea on the corresponding breeding grounds.

Assignment methods, whereby individual birds are assigned to a breeding colony, breeding archipelago, or taxon, are only starting to be used. Banded birds can give information about their origin, but recoveries are typically very few, even when some large-scale banding programs have expended enormous efforts (Browne et al. 2004). Nevertheless, intrinsic markers, either biological (e.g., genetic and morphometric variation) or biogeochemical (stable isotope signatures and trace elements concentrations), open new venues in the assignment of dead birds to their population of origin.

Morphological variation can be used to assess the geographic origin whenever morphotypes are geographically segregated across the breeding range (Webster et al. 2002). Although several studies have shown that the spatial resolution of this approach is often limited (Stratford and Partridge 1996, Cadiou et al. 2003, 2004), examining morphological differences is easy, fast, and inexpensive, and whenever possible should always be considered as a potential tool in assignment studies.

Individual assignment based on genetic data has been extensively used in forensic applications, and their value in the assignment mostly demonstrated (Manel et al. 2005). Most seabird species show strong philopatry and site fidelity (Austin et al. 1994, Bried and Jouventin 2002), which should promote genetic differentiation between populations and thus enhance the potential value of molecular markers for assignment studies. However, recent studies on several seabird species have shown that dispersal plays a major role as a homogenizing force preventing genetic differentiation (see review by Friesen et al. 2007), and thus molecular markers are rendered ineffective (Edwards et al. 2001).

The existence of habitat-specific isotopic signatures also allows the assignment of individuals to their geographic origin (Hobson 2005, Wunder et al. 2005). As tissues incorporate the isotopic content of the prey consumed in a predictable manner, which in turn show spatial structure and pattern in their biogeochemical attributes, these patterns may be used to identify the geographic origin of individuals from any given population. Feather analyses are being extensively used for this purpose, particularly when molting patterns are known, because once formed, feathers become inert, reflecting the elements and the isotopic forms assimilated through the diet when and where they were grown (Chamberlain et al. 1997, Cherel et al. 2000, Becker et al. 2002). Isotopic signatures among different populations can differ for several reasons. Natural isotopic gradients in baseline $\delta^{13} \mathrm{C}$ have been described in the marine environment (Mehl et al. 2004, Forero et al. 2005, Quillfeldt et al. 2005). In addition, differences in diet or foraging behavior among geographically disjunct seabird populations should result in spatial differences in $\mathrm{N}$ and $\mathrm{C}$ isotope values of feathers grown under distinct oceanic conditions (Cherel et al. 2006).

A relatively new approach in the assignment of individuals of unknown origin is the use of trace elements. Recent studies suggest their value as intrinsic markers for assignment studies (Szép et al. 2003, Hobson 2005). Whereas isotope composition mainly differs on a continental or a regional scale $(>1000 \mathrm{~km})$ (Marra et al. 1998), elemental composition of some animal tissues can vary microgeographically (10-1000 $\mathrm{km}$ ) among populations at the local scale (Szép et al. 2003). However, whether trace element concentrations vary in accordance with biogeographical gradients is unclear, and data regarding patterns of variation in the marine environment is still lacking.

Overall, despite the potential value of morphology, molecular markers, trace elements, and stable isotopes for the assignment of individuals of unknown origin, several studies showed little or no geographic structure among populations over regional to local scales (Edwards et al. 2001, Wassenaar and Hobson 2001, Cadiou et al. 2004, Riffaut et al. 2005). Therefore, a thorough examination of the potential strengths and weaknesses of the different types of markers is needed. Differences in the accuracy among intrinsic markers and the potential benefit of combining different approaches have been reported (Royle and Rubenstein 2004, Kelly et al. 2005), but comparative studies and further applications are still scarce, particularly in the marine environment.

In the present study we use the Mediterranean Cory's Shearwater (Calonectris diomedea diomedea; see Plate 1), the Atlantic Cory's Shearwater (Calonectris diomedea borealis), and the Cape Verde Shearwater (C. edwardsii) as a case study in the analysis of different assignment methods to identify the population of origin of oceanic birds. In this paper we aim first to assess the existence of spatial patterns of variation in the three taxa by using genetic, morphometric, and biogeochemical markers. Second, we evaluate the utility of all four markers as effective tools in assigning Calonectris shearwaters to source populations. Finally, we carry out a preliminary application of the results obtained to assign 41 Cory's Shearwaters caught by longliners from Catalonian harbors (northeast Spain) operating on the Mediterranean coast.

\section{Materials and Methodology}

Study species, study area, and sampling design

Cory's Shearwaters breed on islands across the Mediterranean from the Iberian coast to the Adriatic and Aegean (mainly $C$. diomedea diomedea), and in the northeast Atlantic islands, from the Canary to Azores archipelagos (mainly $C$. diomedea borealis), whereas the Cape Verde Shearwater is an endemic of the Cape Verde Archipelago (C. edwardsii) (Appendix A). Although strong patterns of phylogeographic structure have been described within the genus separating the two Cory's 
subspecies and the Cape Verde Shearwater species (Gómez-Díaz et al. 2006), most genetic studies have failed to detect spatial structuring among populations (Randi et al. 1989, Wink et al. 1993, Heidrich et al. 1996, Carneiro da Silva and Granadeiro 1999), but see Rabouam et al. (2000). According to previous genetic studies on the species (Gómez-Díaz et al. 2006), we considered Almeria as an Atlantic Cory's Shearwater colony within the Mediterranean. The Almeria-Oran Oceanographic Front represents a major oceanographic discontinuity in the Mediterranean, and is the real boundary between Atlantic and Mediterranean surface waters (Beckers et al. 1997). The influence of Atlantic waters entering the Mediterranean would explain the pattern observed for Almeria.

From 2001 to 2005 we collected blood samples, the first (innermost) primary feather, and morphometric measurements from adult birds from up to 21 breeding colonies of the Cory's Shearwater across the Mediterranean and the northeastern Atlantic, and one breeding colony of the Cape Verde Shearwater (Fig. 1). In addition, we collected tissue samples, the first primary feather and morphometric measurements from 41 Cory's Shearwaters caught by Mediterranean longliners in 2003 and 2004. Birds were caught during prelaying exodus (7), incubation (3), chick rearing (3), at the end of the breeding period (October) (26), or the postbreeding period (November) (2). In Cory's Shearwater the first primary feather is known to be grown at the end of the breeding period, when parents are still feeding their chicks (Monteiro and Furness 1996; J. González-Solís and E. Gómez-Díaz, personal observation).

We considered three spatial scales in the analyses. First, at a local scale, we considered a colony level corresponding to single breeding colonies at a specific island. At a regional scale we considered an archipelago level, grouping several colonies breeding on geographically neighboring islands (i.e., the Balearic, Azores, and Canary archipelagos). Finally, we grouped colonies into the three main taxa involved: the Atlantic and Mediterranean Cory's Shearwater, and the Cape Verde Shearwater.

\section{Genetic analyses}

Genetic analyses were performed on 188 Cory's and 10 Cape Verde Shearwaters from 21 breeding colonies. We chose the mitochondrial control region as a genetic marker to investigate the genetic structure of the species. As no genetic structure was found below the subspecies level (see Results), we also employed ISSR (Inter Simple Sequence Repeats) multilocus fingerprinting to examine separately closer genetic relationships among Atlantic and Mediterranean Cory's Shearwater breeding colonies.

\section{DNA isolation, amplification, and sequencing}

DNA was isolated from ethanol-preserved whole blood using the salting-out extraction protocol from Bruford et al. (1998). We amplified a 293-bp fragment of
Domain I of the mitochondrial control region of all three Calonectris species using three specific primers that had been designed previously for the species (GómezDíaz et al. 2006): either CAL2H (5'CATCCCATCCAACTTAAG3') or CAL4H (5'AGCCTATGTATGGATGTGCAT3') was used in conjunction with CAL1L (5'GGTCCTGAAGCTAGTAATAC3'). Reaction conditions and automated sequencing were those described by Gómez-Díaz et al. (2006). Representative sequences for each breeding colony are available in GenBank (accession nos. DQ371968-DQ372018).

\section{Population structure}

We evaluated population genetic structure based on the $F_{\mathrm{ST}}$ estimates or Wright's fixation index of population differentiation using the nested analysis of molecular variance (AMOVA) included in ARLEQUIN (Schneider et al. 2000). The AMOVA treatment reflects the correlation of the haplotypic diversity in a hierarchical analysis (Excoffier et al. 1992). In addition, we performed a neighbor-joining clustering analysis, NTsysPC (Version 1.60; Rohlf 1997), based on the $F_{\mathrm{ST}}$ pairwise genetic distances showing genetic relationships among the Cory's Shearwater and the Cape Verde Shearwater colonies. To assess the existence of a spatial pattern in the genetic structure of the species, we tested the correlation between genetic distances, measured as $F_{\mathrm{ST}} /\left(1-F_{\mathrm{ST}}\right)$, and geographic distances, calculated as $\ln$ (geographic distance by sea) of population pairs (Rousset 1997). We applied Procrustes analysis (leastsquares orthogonal mapping) a nonparametric approach for the comparison of the two kinds of nonlinearized data sets, using SPSS 12.0 (SPSS 2003). The method is based on matching corresponding points (landmarks) from each of the two data sets, and provides a measure of fit $\left(\mathrm{m}^{2}\right)$. The significance test of the $m^{2}$ statistic was determined by employing a randomization approach to one of the data sets (Protest).

\section{ISSR fingerprint}

We screened a subset of samples with six RAPD (Random Amplified Polymorphic DNA) and two ISSR (Inter Simple Sequence Repeats) markers. Based on clarity and resolution of fingerprint profiles from this screening, we chose the two ISSR markers ((ACTG $\left.(\mathrm{AC})_{7}\right)$ and (GTCAAGG $(\mathrm{CT})_{6}$ ), which produced scoreable and highly polymorphic PCR products. To avoid intra-assay variability, the amplification protocol was performed below high-stringency conditions and PCR reactions were established according to a standardized protocol (Arribas et al. 1997) with annealing at $65^{\circ} / 50^{\circ} \mathrm{C}$ (AC/CT primer). We electrophoresed PCR (Polymerase Chain Reaction) products on an $8 \mathrm{~mol} / \mathrm{L}$ urea $/ 6 \%$ polyacrylamide sequencing gel. ISSR markers were detected by silver staining (Bassam et al. 1991). First, we performed duplicate PCR reactions in a control set of individuals to evaluate the reproducibility of ISSR 


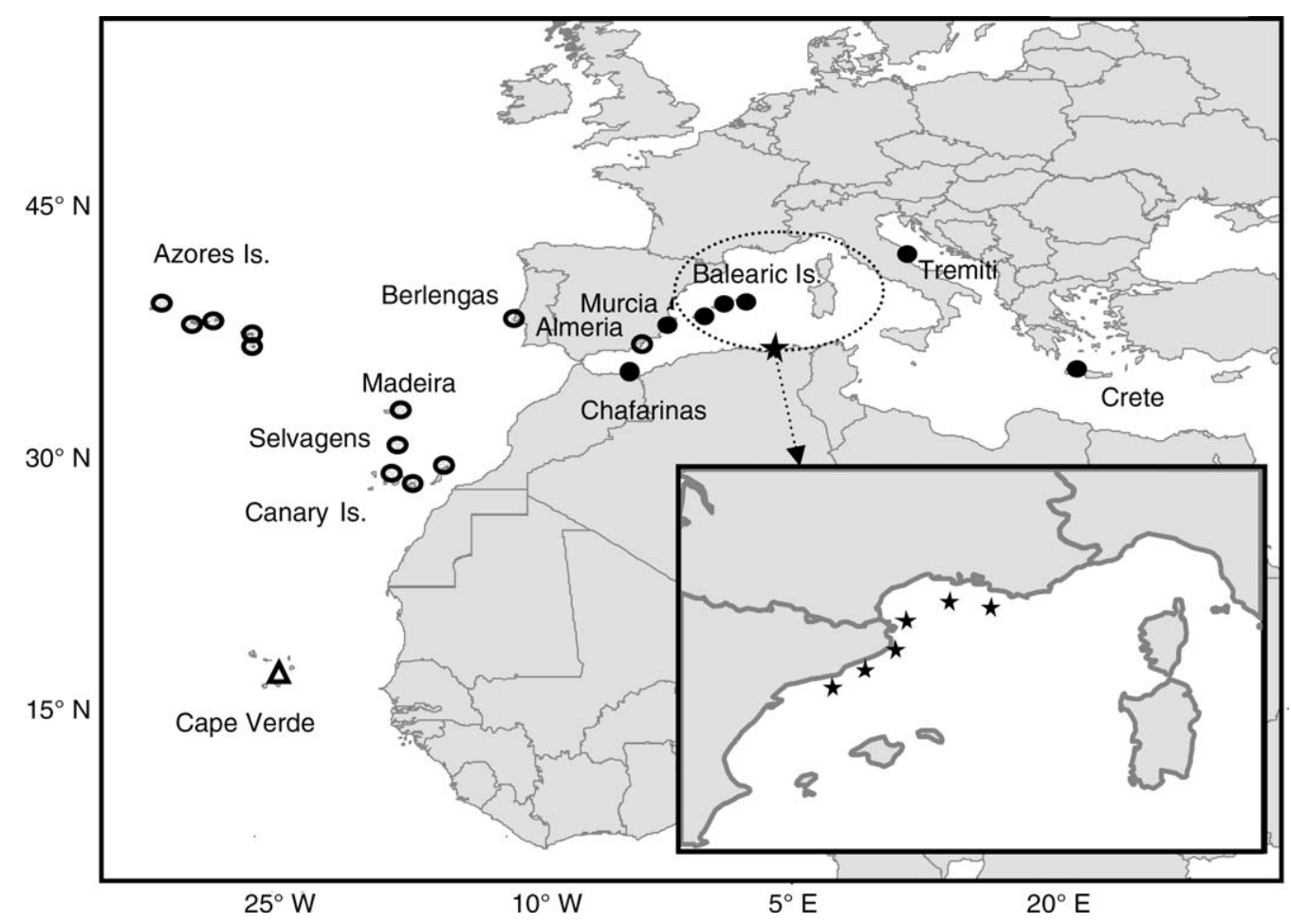

FIG. 1. Breeding colonies of Cory's Shearwater and the Cape Verde Shearwater sampled across the Mediterranean and the Atlantic. The Mediterranean (solid circles), the Atlantic (open circles), and Cape Verde Shearwater (open triangle) breeding colonies (Calonectris diomedea diomedea, C. diomedea borealis, and C. edwardsii, respectively) and locations where bycatch Cory's Shearwaters were caught (stars) are indicated.

fragments. We checked repeatability for independent DNA extractions, different PCR reactions, and different PCR runs to explore all possible sources of error, and we excluded for subsequent statistical analyses nonreproducible bands as well as faint bands (Pérez et al. 1998). All the scoring was repeated twice, and to further avoid biased results, analyses were restricted to breeding colonies with a sample size $>10$ birds (Nybom 2004). For the data analysis, assumptions following analytical procedures by Lynch and Milligan (1994) were applied.

\section{Biometric analysis}

We performed a clustering analysis on the biometric data to assess the population structure and the degree of morphologic differentiation among Cory's Shearwater colonies and the Cape Verde Shearwater across its geographical distribution. Birds were sexed using the molecular method described by Fridolfsson and Ellegren (1999). We included six biometric measures: tarsus, wing, maximum head (cranium length plus the bill length) and bill length, bill depth, and bill depth at nostril, of 703 sexed individuals from 19 distinct colonies. To remove the effect of sexual size dimorphism on the assessment of morphometric differences among breeding colonies, morphometric variables of males and females were standardized by subtracting the species mean of each sex. We calculated the Euclidean distance for all pairwise combinations of populations and constructed a cladogram from the similarity matrix using the Neighbor-Joining clustering analysis implemented in the NTSYSpc package version 2.1 (Rohlf 1997). To investigate the existence of spatial gradients in morphology, we tested the relationship between each of the six morphometric measures and the corresponding latitude and longitude coordinates of the sampled colonies by least square and curvilinear regressions using the SPSS 12.0 package (SPSS 2003).

\section{Isotopic and trace elements analysis}

We analyzed $\mathrm{C}$ and $\mathrm{N}$ stable isotope signatures and trace element concentration on the first primary feather of 219 individuals from 17 breeding colonies. First, feathers were cleaned from surface contaminants using $\mathrm{NaOH}$ and ground to powder using a SPEX 6750 Freezer/Mill (SPEX CertiPrep, Metuchen, New Jersey, USA). To analyze stable isotopes, $0.3 \mathrm{mg}$ of this powder was weighed to the nearest microgram and placed into a $\mathrm{Sn}$ (tin) capsule. Samples were oxidized with $\mathrm{CuO}$ and $\mathrm{CO}_{3} \mathrm{O}_{4} / \mathrm{Ag}$ at about $900^{\circ} \mathrm{C}$ in a Flash EA 1112 Elemental Analyser (CE Elantech, Lakewood, New Jersey, USA) coupled to a pirolizator TC-EA and a breath bench, through an interface Conflo III (Finnigan MAT, San Jose, California, USA). $\mathrm{NO}_{\mathrm{x}}$ was reduced with $\mathrm{Cu}$ at $680^{\circ} \mathrm{C}$. The combustion products, $\mathrm{N}_{2}$ and $\mathrm{CO}_{2}$, were dried using $\mathrm{MgClO}_{4}$ and transported to a Delta C Finnigan MAT mass spectrometer (Isotopic 
ratio mass spectrometry, Serveis Científico-Tècnics of University of Barcelona, Barcelona, Spain). International standards were run with each of 12 samples; IAEA $\mathrm{CH}_{7}\left(87 \%\right.$ of C), IAEA $\mathrm{CH}_{6}$ (42\% of C) and USGS 24 $\left(100 \%\right.$ of $\mathrm{C}$ ) for ${ }^{13} \mathrm{C}$ and IAEA N1 and IAEA N2 (with $21 \%$ of $\mathrm{N})$ and IAEA $\mathrm{NO}_{3}(13.8 \%$ of $\mathrm{N})$ for ${ }^{15} \mathrm{~N}$.

For the analysis of trace elements, $0.1 \mathrm{~g}$ of feather powder was digested in $1 \mathrm{~mL}$ of nitric acid and $0.5 \mathrm{~mL}$ of hydrogen peroxide using teflon bombs for 12 hours at $60^{\circ} \mathrm{C}$. The result of the digestion was diluted in $7 \mathrm{~mL}$ of distilled water. Analyses were performed using the Atomic Adsorption Spectrophotometry (AAS) technique with a mass Perkin Elmer Optima 6000 Elan Spectrophotometer (Isotopic ratio mass spectrometry, Serveis Científico-Tècnics of University of Barcelona, Barcelona, Spain). Accuracy of analysis was checked by measuring certified reference material (Human Hair CRM 397). To check the reproducibility of the procedure, we included sample replicates as well as negative controls in each set of samples analyzed. In addition, we replicated the analysis in 50 of the samples selected at random. We compared mean breeding colony values of trace element composition between replicates using $t$ tests for two related samples (SPSS 2003). Only those elements showing significant correlations, $R^{2}>0.5$ and no significant differences in mean breeding colony values between the two analyses, were considered for the assignment analyses.

First, to evaluate the degree of structuring among Cory's and the Cape Verde Shearwater colonies, for both $\mathrm{C}$ and $\mathrm{N}$ stable isotope and trace elements, we calculated the Euclidean distance for all pairwise comparisons of mean colony values and constructed a cladogram from the similarity matrix using the Neighbor-Joining clustering analysis implemented in the NTSYSpc package version 2.1 (Rohlf 1997). Second, to investigate the existence of spatial gradients, we tested the relationships of carbon and nitrogen isotopic signatures and trace element concentrations with the corresponding latitude and longitude coordinates of the sampled colonies by least-square and curvilinear regression using the SPSS 12.0 package (SPSS 2003).

\section{Assignment analyses}

Assignment tests on multilocus ISSR data were performed using DOH (Paetkau et al. 1995), a frequency-based program. We split our data set into both baseline data, to calculate population frequency likelihoods, and test data, for the frequency-based assignment, randomly grouping $80 \%$ and $20 \%$ of the individuals, respectively.

We employed classificatory discriminant analysis (SPSS 2003) to evaluate the ability of morphometrics, stable isotopes, and trace elements in the assignment of birds to their geographical origin. Trace element concentrations were transformed logarithmically to approach normality. We carried out the analysis separately and in combination using the same subset of birds (185 individuals from 15 breeding colonies). For all the analyses, we split the original data set into training data, to build models, and an independent data set, to test the classificatory method, randomly grouping $70 \%$ and $30 \%$ of the individuals, respectively. In addition, we tested models by jackknife cross-validation. Models were built step by step, including independent variables according to the Wilks' lambda criterion, and colonies were weighted according to the sample size. Discriminant functions were used to classify the individuals previously excluded in testing for the accuracy of the model. Validation of the model was further examined using samples from three distinct Cory's Shearwater colonies sampled in previous years and analyzed separately.

After comparing all three assignment approaches (see Results), we built a final model using trace elements and stable isotopes on a larger data set, covering almost the entire breeding range of the species, and applied this model to assign 41 bycatch Cory's Shearwaters.

\section{Results}

Genetics

Clustering analysis on mtDNA data indicated a clear geographical pattern; three groups of colonies corresponded to each of the two geographically isolated Cory's Shearwater subspecies and the Cape Verde species (Fig. 2A).

AMOVA results suggested strong genetic structuring among the three main taxa $\left(F_{\mathrm{CT}}=0.61, P<0.001\right)$. The largest variance component was due to differences among subspecies (60.5\%); whereas within each subspecies, among breeding colonies, the variance component was lower (37.2\%). However, a second AMOVA, at a local scale, failed to reveal genetic structuring among breeding colonies within either the Atlantic or the Mediterranean subspecies region $\left(F_{\mathrm{ST}}=0.040, P=\right.$ $0.350 ; F_{\mathrm{ST}}=0.00, P=0.450$, respectively).

Procrustes analyses revealed a significant correlation between genetic and geographic distances among colonies considering both the Atlantic and the Mediterranean Cory's Shearwater subspecies regions $\left(m^{12}=\right.$ 0.63, $P<0.001)$. However, at a local scale among colonies within each subspecies region, the correlation was lower. Whereas spatial correlation was still significant within the Mediterranean $\left(m^{12}=0.63, P=0.020\right)$, significance did not hold within the Atlantic $\left(m^{12}=0.93\right.$, $P=0.716)$.

\section{Biometrics}

The cladogram represents the similarity pattern of the 19 breeding colonies included in the analysis, considering six biometric measures (Fig. 2B). Three groups were clearly defined, corresponding to each of the three taxa. A first group included populations corresponding to the largest in size, the Atlantic Cory's Shearwater. All Mediterranean breeding colonies grouped separately corresponding to the intermediate in body size, the 

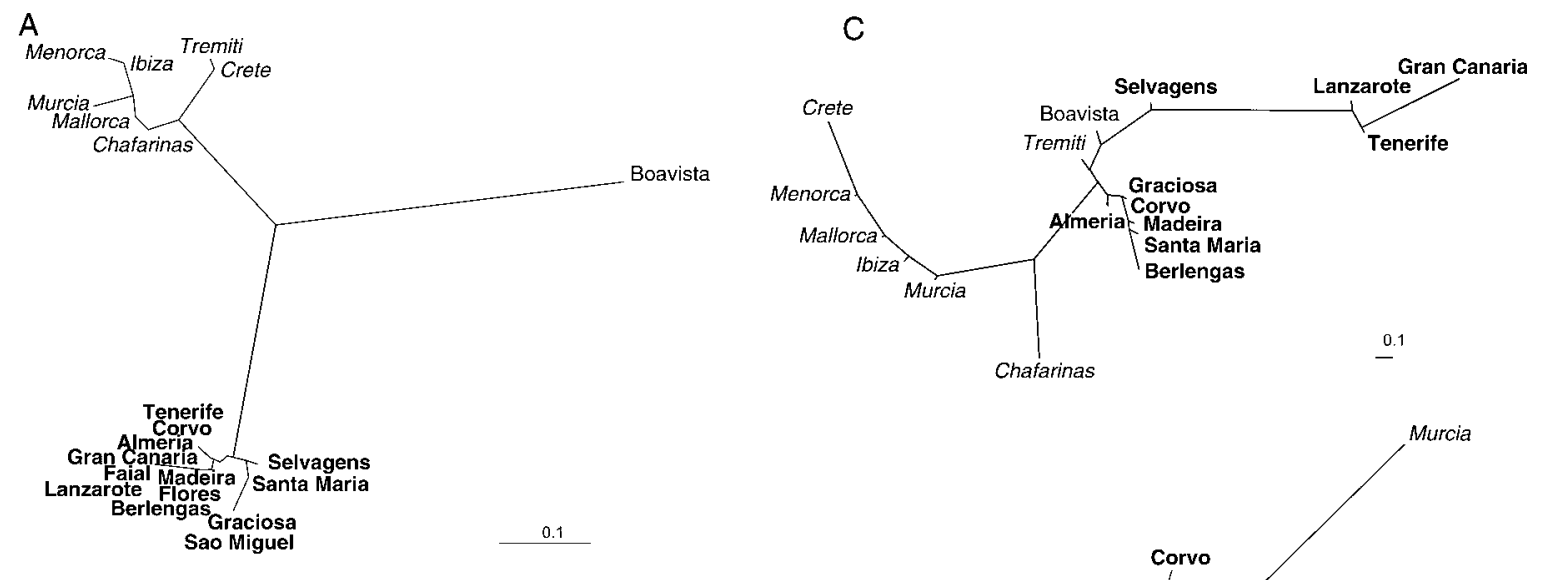

\section{B}
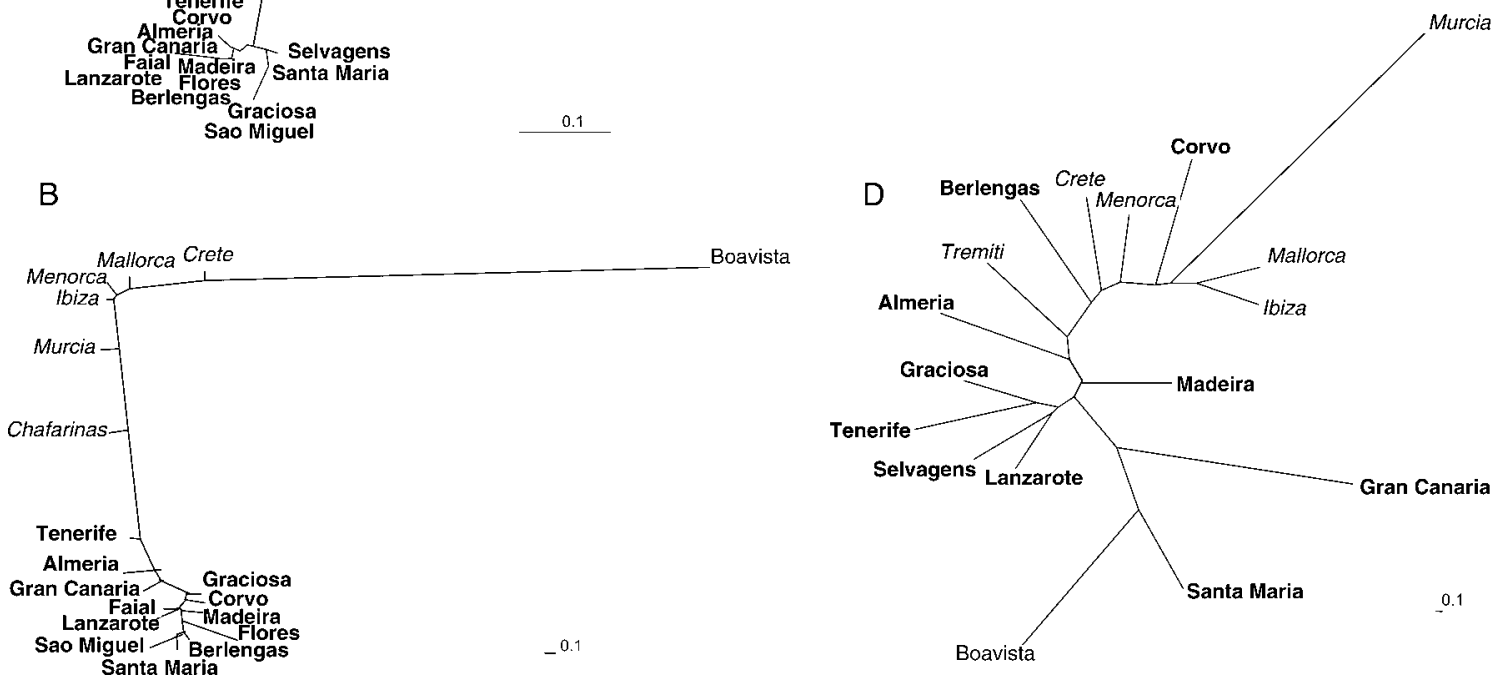

FIG. 2. Neighbor-joining cladogram showing relationships among Cory's and Cape Verde Shearwater breeding colonies based on (A) genetic, (B) biometric, (C) $\delta^{13} \mathrm{C}$ and $\delta^{15} \mathrm{~N}$ signatures, and (D) trace elements composition of first primary feathers. Groups corresponding to the Atlantic Cory's, Mediterranean Cory's, and Cape Verde Shearwater breeding colonies are indicated by boldface type, italics, and lightface type, respectively. Biometric, trace elements, and isotope cladograms are based on Euclidean pairwise distances among colonies. The genetic cladogram is based on $F_{\mathrm{ST}}$ pairwise genetic distances among colonies; the length of the scale bar in each graph represents 0.1 units of distance.

Mediterranean Cory's Shearwater. The smallest in size, the Cape Verde Shearwater breeding colony, was grouped separately.

Linear regression analyses revealed a significant positive longitudinal pattern within the Mediterranean subspecies in three of six biometric measures for males and females (tarsus: $R^{2}=0.16, n=108, P<0.001$ and $R^{2}$ $=0.10, n=94, P=0.002$; bill depth at nostril: $R^{2}=0.24$, $n=108, P<0.001$ and $R^{2}=0.13, n=96, P<0.001$; bill depth: $R^{2}=0.13, n=108, P<0.001$ and $R^{2}=0.14, n=$ 96, $P<0.001$, for males and females, respectively). For the Atlantic subspecies no significant association was found between any of the six measures and either longitude or latitude (all measures: $R^{2}<0.15, n=224$ and $R^{2}<0.05, n=228$, for males and females, respectively). Both linear and quadratic regression coefficients and $F$ statistics are shown in Appendix D. In a few cases quadratic models fit substantially better than linear models.

\section{Isotopes and trace elements}

The cladogram based on carbon and nitrogen signatures grouped most breeding colonies according to their geographical distributions. All Mediterranean breeding colonies grouped together except Tremiti, ungrouped, and Almeria, grouped within the Atlantic cluster. In the Atlantic, northeast and southeast Atlantic breeding colonies grouped separately (Fig. 2C). The similarity tree based on trace elements composition showed no geographical structure among breeding colonies, nor among the three main taxa. Nevertheless, breeding colonies appeared well differentiated and large distances separated each node (Fig. 2D).

Regression models based on stable isotope composition of primary feathers showed significant spatial gradients for both $\delta^{15} \mathrm{~N}$ and $\delta^{13} \mathrm{C}$ values across the breeding range of the study species (Fig. 3; Appendix C). Regression coefficients and $F$ statistics are shown in Appendix D. Least squares regression models, although significant, did not explain much variability, whereas curvilinear models, in particular cubic regressions, better fit the spatial gradients observed (Appendix D). Carbon isotope ratios were associated with latitude $\left(R^{2}=0.17\right.$ and 0.24 ; least squares and cubic regression, respectively) (Fig. 3A), decreasing from south (Gran Canaria Island, $\left.\delta^{13} \mathrm{C}=-13.34 \pm 0.69\right)$ to north (Menorca Island, 

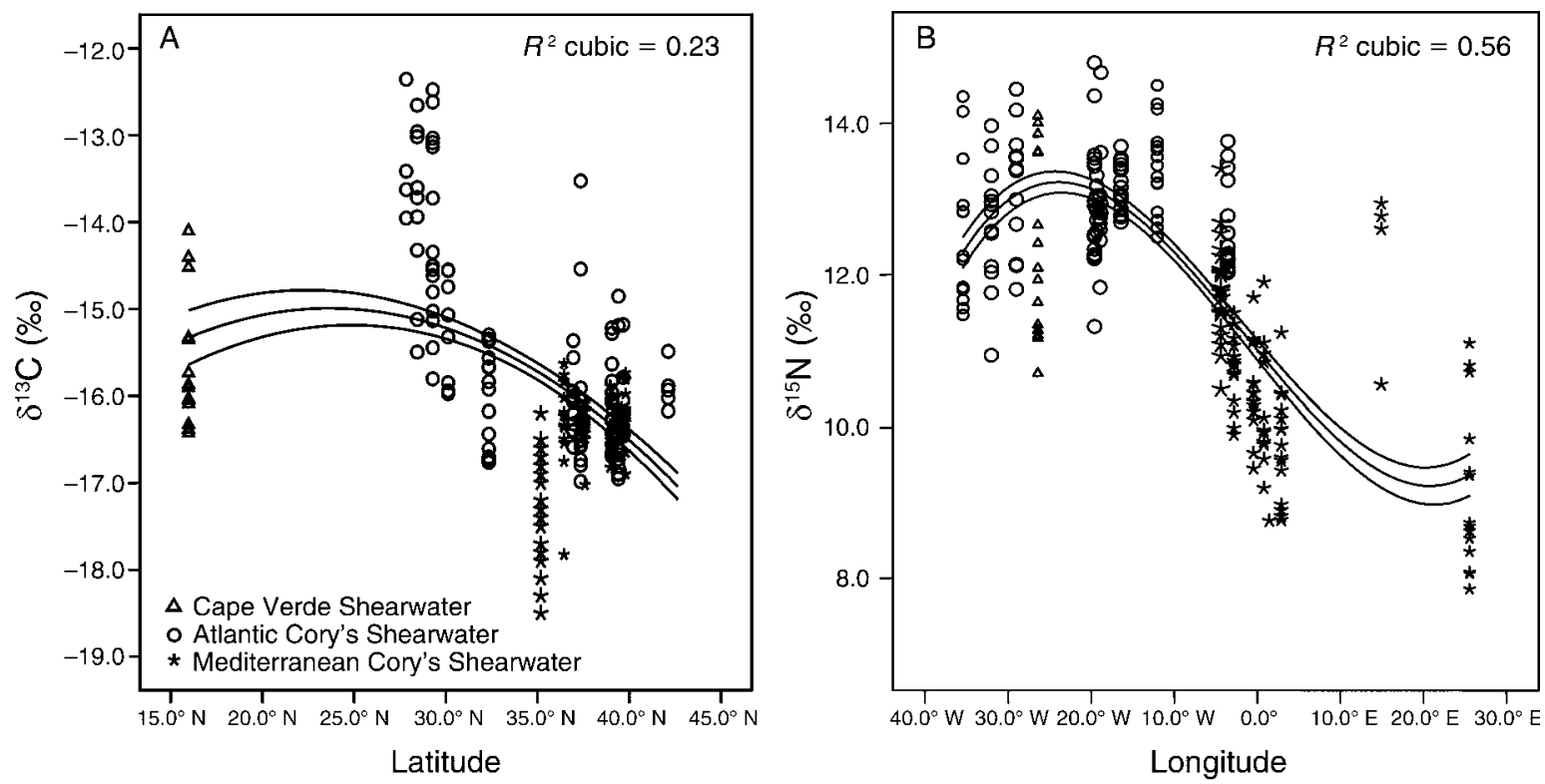

FIG. 3. Relationships between (A) $\delta^{13} \mathrm{C}$ feather signatures and latitude, and (B) $\delta^{15} \mathrm{~N}$ feather signatures and longitude. Note the decreasing trend from west to east in $\delta^{15} \mathrm{~N}$, whereas $\delta^{13} \mathrm{C}$ values tend to decrease from north to south across the breeding range of the species. " $R^{2}$ cubic" means $R^{2}$ for cubic regression.

$\left.\delta^{13} \mathrm{C}=-16.23 \pm 0.32\right)$, except for the most southern Cape Verde breeding colony, which showed unexpected low values $\left(\delta^{13} \mathrm{C}=-15.66 \pm 0.76\right)$. No significant association was found between carbon isotopic signatures and longitude $\left(R^{2}=0.06\right)$. At a local scale, within each Cory's subspecies region, the latitudinal decrease in carbon values was further apparent within the Atlantic ( $R^{2}=0.49$ and 0.61 ; least squares and cubic regression) (Fig. 4A), but also within the Mediterranean $\left(R^{2}=0.35\right.$ and 0.39 ; linear and cubic regression).

Globally, nitrogen isotope values in feathers tended to show an inverse relationship with longitude, decreasing from west to east $\left(R^{2}=0.45\right.$ and 0.56 ; least squares and cubic regression) (Fig. 3B). Indeed, significant differences in mean nitrogen isotopic signatures split the eastern C. diomedea diomedea $\left(\delta^{15} \mathrm{~N}=10.57 \pm 1.34\right)$ from the western $C$. diomedea borealis breeding colonies $\left(\delta^{15} \mathrm{~N}=\right.$ $12.97 \pm 0.74 ; t=-15.36, P<0.001)$. However, the colony from Tremiti showed greater nitrogen isotope values $\left(\delta^{15} \mathrm{~N}=12.28 \pm 1.03\right)$ than those reported within the entire Mediterranean $\left(\delta^{15} \mathrm{~N}=10.57 \pm 1.34\right)$. No significant association was found between nitrogen isotope values and latitude $\left(R^{2}=0.07\right)$. Considering each subspecies range separately, nitrogen isotope values tended to decrease with longitude within the Mediterranean $\left(R^{2}=0.23\right.$ and 0.64 ; least squares and cubic regression) (Fig. 4B), whereas no pattern was apparent within the Atlantic $\left(R^{2}=0.07\right.$ and 0.08 ; linear and cubic regression; Appendix D).

Results from ANOVA showed significant differences in trace element composition $(\mathrm{Na}, \mathrm{Mg}, \mathrm{Mn}, \mathrm{Ba}, \mathrm{S}, \mathrm{Zn}$, $\mathrm{Al}, \mathrm{P}, \mathrm{Ca}, \mathrm{Cr}, \mathrm{Rb}, \mathrm{Sr}, \mathrm{Sb}, \mathrm{La}, \mathrm{Ce}, \mathrm{Pr}, \mathrm{Nd}, \mathrm{Hg}$, and U) of primary feathers across the study species range (all $P<$
0.001) (Appendix B). Most elements showed weak associations with either latitude or longitude (least squares and cubic regression coefficients, $R^{2}$, ranging from 0 to 0.20 ). Only a few elements showed $R^{2}>0.20$ (Appendix D). That is, $\mathrm{Mg}, \mathrm{Sr}$, and $\mathrm{U}$ concentrations varied with longitude across the breeding range $\left(\mathrm{Mg}, R^{2}\right.$ $=0.20, \mathrm{Sr}, R^{2}=0.23$, and $\mathrm{U}, R^{2}=0.34$; for cubic regression), and $\mathrm{Hg}$ was mainly associated with latitude ( $R^{2}=0.28$ and 0.37 ; least squares and cubic regression). No significant spatial correlations were found in $\mathrm{Hg}$ levels within the Atlantic or the Mediterranean. In contrast, $\mathrm{Mg}, \mathrm{Sr}$, and $\mathrm{U}$ were notably associated with longitude within the Mediterranean subspecies range $\left(\mathrm{Mg}, R^{2}=0.27\right.$ and $0.42, \mathrm{Sr}, R^{2}=0.25$ and 0.45 , and $\mathrm{U}$, $R^{2}=0.35$ and 0.44 , for least squares and cubic regression, respectively.) (Regression coefficients and $F$ statistics are shown in Appendix D.)

\section{Geographic assignment}

Genetic assignment based on ISSR data failed to assign individuals to breeding colonies. In the randomization procedure only 62 out of 313 Cory's Shearwaters were assigned to the putative colony. The rate of correct assignment was $22.4 \%$ among breeding colonies for the Mediterranean Cory's Shearwater subspecies, whereas in the Atlantic only $16.8 \%$ of individuals were correctly classified. For the independent data set $11.5 \%$ and $11.9 \%$ of individuals were correctly assigned among the Atlantic and the Mediterranean subspecies, respectively.

The discriminant analysis based only on trace elements composition achieved the best rate of correct assignment at both colony and archipelago levels, whereas discriminant models based only on either 

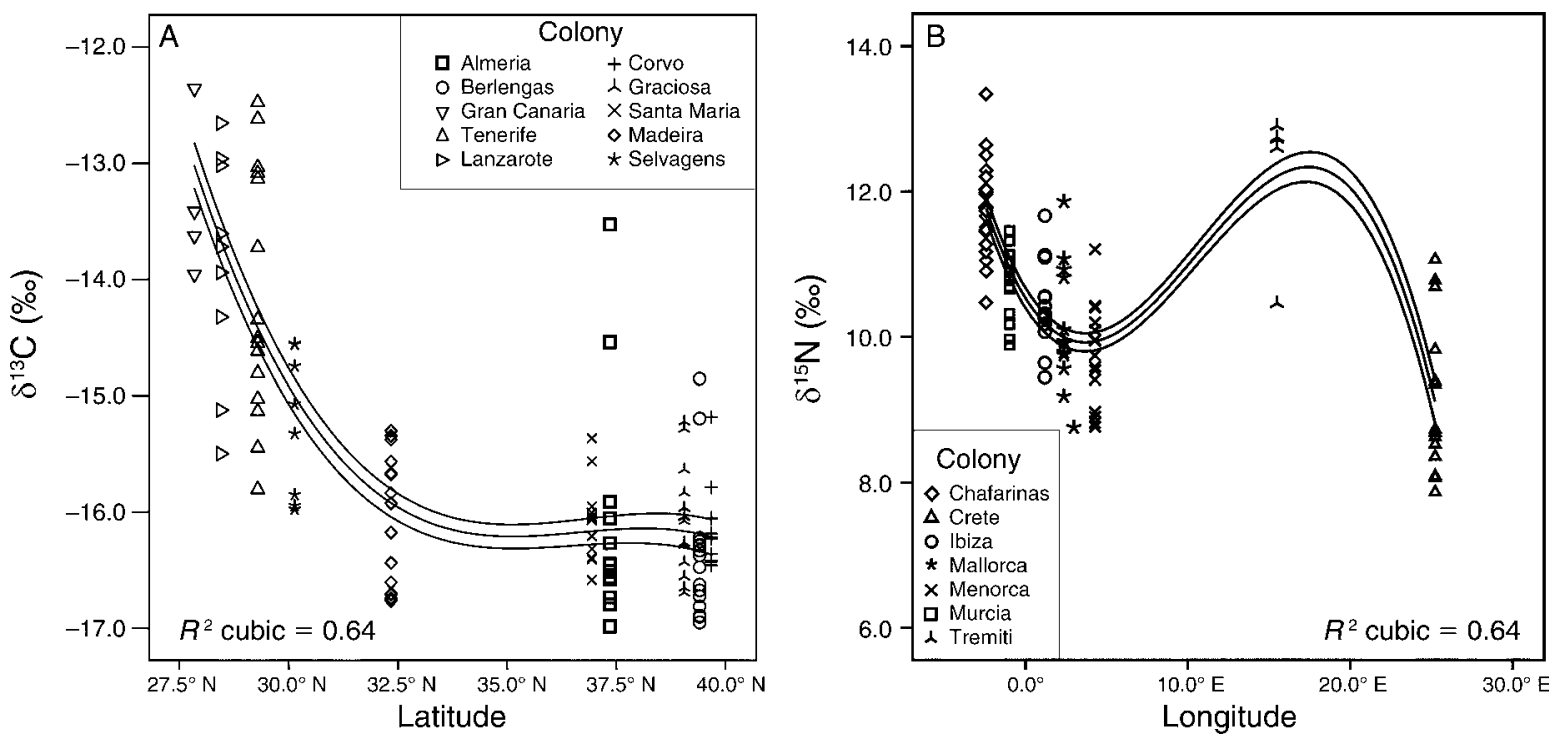

FIG. 4. Significant associations between geographic coordinates and stable isotopes within each subspecies region are shown; either (A) between $\delta^{13} \mathrm{C}$ signatures and latitude among Atlantic Cory's Shearwater breeding colonies, or $(\mathrm{B})$ between $\delta^{15} \mathrm{~N}$ and longitude among Mediterranean Cory's Shearwater breeding colonies. " $R^{2}$ cubic" means $R^{2}$ for cubic regression.

morphometric measures or stable isotopes just showed high rates of correct assignment among taxa (Table 1). In both independent data set and independent analysis, the ability to correctly classify individuals dropped noticeably in all three assignment approaches when used separately; the more detailed the scale of the analysis, the larger the drop (Table 1). Combining different approaches substantially improved the rate of correct assignments at both colony and archipelago levels in most cases. Models based on isotopes and trace elements, as well as models including those with morphology, achieved the best assignment results. Cross-validations, independent data, and independent analysis further confirmed the ability of the combined models, based only on isotopes and trace elements or together with morphology, to discriminate among geographic origins (Table 1).

A final model built on 219 individuals from 17 breeding colonies combined $\mathrm{C}$ and $\mathrm{N}$ isotopic signatures and trace element concentrations, to assign bycatch birds whose origin was unknown. Discriminant analysis achieved rates of correct assignment $>80 \%$ for all the

TABLE 1. Classification rates obtained for each assignment method at each scale of analysis when used alone and in conjunction.

\begin{tabular}{|c|c|c|c|c|c|c|c|}
\hline Scale & Biometrics & Isotopes & Elements & $\begin{array}{l}\text { Biometrics } \\
\text { and isotopes }\end{array}$ & $\begin{array}{l}\text { Biometrics } \\
\text { and elements }\end{array}$ & $\begin{array}{c}\text { Isotopes } \\
\text { and elements }\end{array}$ & $\begin{array}{l}\text { Biometrics and } \\
\text { isotopes and } \\
\text { elements }\end{array}$ \\
\hline \multicolumn{8}{|c|}{ Training data $(n=130)$} \\
\hline Colony & 27.1 & 38.0 & 77.5 & 46.5 & 82.9 & 82.2 & 86.0 \\
\hline Archipelago & 41.9 & 58.9 & 75.2 & 65.1 & 76.0 & 83.7 & 90.7 \\
\hline Taxa & 87.6 & 89.9 & 89.9 & 99.2 & 98.4 & 96.9 & 100.0 \\
\hline \multicolumn{8}{|l|}{ Test data $(n=56)$} \\
\hline Colony & 14.3 & 33.9 & 62.5 & 41.1 & 48.2 & 66.1 & 62.5 \\
\hline Archipelago & 48.2 & 53.6 & 69.6 & 64.3 & 75.0 & 80.4 & 82.1 \\
\hline Taxa & 83.9 & 89.3 & 89.3 & 98.2 & 98.2 & 96.4 & 98.2 \\
\hline \multicolumn{8}{|l|}{ Cross-validation } \\
\hline Colony & 22.5 & 28.7 & 56.6 & 31.0 & 65.1 & 62.8 & 69.8 \\
\hline Archipelago & 41.1 & 52.7 & 70.5 & 61.2 & 69.0 & 76.0 & 79.8 \\
\hline Taxa & 84.5 & 89.9 & 86.0 & 98.4 & 96.9 & 92.2 & 100.0 \\
\hline \multicolumn{8}{|c|}{ Independent analysis $(n=17)$} \\
\hline Colony & 17.6 & 11.8 & 23.5 & 17.6 & 29.4 & 41.2 & 58.8 \\
\hline Archipelago & 52.9 & 70.6 & 41.2 & 64.7 & 47.1 & 88.2 & 94.1 \\
\hline Taxa & 64.7 & 94.1 & 58.8 & 88.2 & 70.6 & 70.6 & 88.2 \\
\hline
\end{tabular}

Notes: Correct assignments (percentages) are shown for training data, test data, jackknife cross-validation, and independent analysis. Independent test data were the $30 \%$ of the data randomly excluded prior to building the discriminant model. Independent test analysis corresponded to samples collected in previous years and analyzed separately. 
TABLE 2. Assignment rates, validations, and misclassifications (training data) of the final discriminant model, based on stable isotope signatures $(\mathrm{C}$ and $\mathrm{N}$ ) and trace elements composition of the first primary feather of 226 Cory's Shearwaters from 17 breeding colonies.

\begin{tabular}{|c|c|c|c|c|c|c|}
\hline \multirow[b]{2}{*}{ Taxon } & \multirow[b]{2}{*}{ Archipelago } & \multirow[b]{2}{*}{$\begin{array}{l}\text { Breeding } \\
\text { colony }\end{array}$} & \multirow[b]{2}{*}{$N$} & \multicolumn{2}{|c|}{ Training data } & \multirow[b]{2}{*}{ Misassignments } \\
\hline & & & & $\begin{array}{c}\text { No. } \\
\text { assigned }\end{array}$ & $\begin{array}{l}\text { Assigned } \\
(\%)\end{array}$ & \\
\hline Atlantic Cory's Shearwater & Azores Is. & St. Maria & 13 & 12 & 92.3 & Cape Verde \\
\hline Atlantic Cory's Shearwater & Azores Is. & Graciosa & 17 & 15 & 88.2 & Berlengas, Madeira \\
\hline Atlantic Cory's Shearwater & Azores Is. & Corvo & 13 & 10 & 76.9 & $\begin{array}{l}\text { Ibiza, Berlengas, } \\
\text { Madeira }\end{array}$ \\
\hline Atlantic Cory's Shearwater & Canary Is. & Gran Canaria & 4 & 4 & 100.0 & \\
\hline Atlantic Cory's Shearwater & Canary Is. & Lanzarote & 18 & 15 & 83.3 & $\begin{array}{l}\text { Selvagens, Madeira, } \\
\text { Graciosa }\end{array}$ \\
\hline Atlantic Cory's Shearwater & Canary Is. & Tenerife & 9 & 8 & 88.9 & Graciosa \\
\hline Atlantic Cory's Shearwater & Madeira & Madeira & 18 & 16 & 88.9 & Graciosa, Ibiza \\
\hline Atlantic Cory's Shearwater & Selvagens & Selvagens & 8 & 7 & 87.5 & Graciosa \\
\hline Atlantic Cory's Shearwater & Berlengas & Berlengas & 18 & 18 & 100.0 & \\
\hline Atlantic Cory's Shearwater & Almeria & Almeria & 15 & 14 & 93.3 & Madeira \\
\hline Mediterranean Cory's Shearwater & Balearic Is. & Mallorca & 12 & 7 & 58.3 & Menorca, Ibiza \\
\hline Mediterranean Cory's Shearwater & Balearic Is. & Menorca & 15 & 11 & 73.3 & Mallorca, Ibiza \\
\hline Mediterranean Cory's Shearwater & Balearic Is. & Ibiza & 15 & 12 & 80.0 & Mallorca, Crete \\
\hline Mediterranean Cory's Shearwater & Murcia & Murcia & 15 & 15 & 100.0 & \\
\hline Mediterranean Cory's Shearwater & Tremiti & Tremiti & 5 & 5 & 100.0 & \\
\hline Mediterranean Cory's Shearwater & Crete & Crete & 15 & 9 & 60.0 & $\begin{array}{l}\text { Menorca, Ibiza, } \\
\text { Berlengas }\end{array}$ \\
\hline Cape Verde Shearwater & Cape Verde & Boavista & 15 & 14 & 93.3 & Gran Canaria \\
\hline
\end{tabular}

Notes: $N$ denotes sample size, and "No. assigned" denotes the number of birds assigned to the putative colony. Assignments for 41 bycatch Cory's Shearwaters of unknown origin and dates when the birds were caught are also shown. Misassignments correspond to training data.

scales of the analysis $(80.2 \%$ among colonies, $87.4 \%$ considering archipelagos, and $98.1 \%$ among taxa) (Table 2). Cross-validations, independent data sets and independent analysis confirmed the utility of the model to discriminate among geographic origins $(73.5,75$, and $64.7 \%$ of correct assignments among colonies). The discriminant model for the whole data set $(100 \%$ of cases) included $\delta^{15} \mathrm{~N}\left(F_{10,215}=71.58, P<0.001\right)$, $\mathrm{Sr}$ $\left(F_{20,428}=53.86, P<0.001\right), \delta^{13} \mathrm{C}\left(F_{30,625}=46.50, P<\right.$ $0.001)$, $\mathrm{Ca}\left(F_{40,805}=39.17, P<0.001\right)$, Sb $F_{50,965}=$ $33.10, P<0.001), \mathrm{Hg}\left(F_{60,1105}=28.64, P<0.001\right), \mathrm{Mn}$ $\left(F_{70,1225}=25.70, P<0.001\right)$, Ce $\left(F_{80,1327}=23.70, P<\right.$ $0.001), \mathrm{Ba}\left(F_{90,1414}=21.99, P<0.001\right), P\left(F_{100,1486}=\right.$ $20.34, P<0.001), \mathrm{U}\left(F_{110,1547}=18.90, P<0.001\right)$, and $\mathrm{Na}\left(F_{120,1597}=17.72, P<0.001\right)$. The preliminary application of the discriminant model combining isotopes and trace elements on 41 Cory's Shearwaters caught by Mediterranean longliners assigned individuals to Menorca (48.8\%), Ibiza (14.6\%), Crete (31.7\%), and one Atlantic breeding colony (Graciosa, 4.8\%). Locations where bycatch birds were caught are shown in Fig. 1 , and the corresponding bycatch dates are indicated in Table 2.

\section{DisCUSSION}

\section{Genetics}

Mitochondrial DNA analyses revealed a strong genetic structuring among the three main taxa, agreeing with their geographically segregated distributions (Fig. 2A). However, the Mediterranean colony of Almeria was placed within the Atlantic cluster. This result agrees with previous genetic studies on the species, pointing out the Atlantic subspecies identity of Almeria (Gómez-Díaz et al. 2006).

The mitochondrial control region is a rapidly evolving locus extensively used for population-level studies (see Pearce 2006), and its potential utility to discriminate among geographic origins has been previously shown in a number of species (Lovette et al. 2004). However, this gene appeared ineffective for the geographic assessment of Cory's Shearwaters beyond the taxon level. Similarly, although ISSR multilocus fingerprints revealed substantial genetic variability, assignment tests failed to classify individuals to the breeding colony. The low level of genetic structuring observed for both molecular markers explains the weak spatial resolution and the low rates of correct assignments. Lack of genetic structure has been repeatedly reported for the species using different genetic markers (Randi et al. 1989, Wink et al. 1993, Heidrich et al. 1996, Carneiro da Silva and Granadeiro 1999, Gómez-Díaz et al. 2006). Analyses based on microsatellite fingerprints found genetic structuring at lower levels, both among and within breeding sites, but failed to detect a correlation between spatial and genetic patterns of variation (Rabouam et al. 2000).

\section{Biometrics}

The biometric pattern of variation matched the geographical distributions of the three taxa separating the two Cory's Shearwater subspecies and the Cape Verde Shearwater (Fig. 2B). But in agreement with 
TABLE 2. Extended.

\begin{tabular}{|c|c|c|c|}
\hline \multicolumn{2}{|c|}{ Cross-validation } & \multicolumn{2}{|c|}{ Application data (bycatch birds) } \\
\hline $\begin{array}{c}\text { No. } \\
\text { assigned }\end{array}$ & $\begin{array}{c}\text { Assigned } \\
(\%)\end{array}$ & $\begin{array}{l}\text { Assigned } \\
(\%)\end{array}$ & $\begin{array}{l}\text { Collection dates } \\
\text { (no. birds) }\end{array}$ \\
\hline 10 & 76.9 & & \\
\hline 13 & 76.5 & 4.9 & May (1), August (1) \\
\hline 9 & 69.2 & & \\
\hline 3 & 75.0 & & \\
\hline 14 & 77.8 & & \\
\hline 7 & 77.8 & & \\
\hline 13 & 72.2 & & \\
\hline 4 & 50.0 & & \\
\hline 17 & 94.4 & & \\
\hline 13 & 86.7 & & \\
\hline 6 & 50.0 & & \\
\hline 9 & 60.0 & 48.8 & $\begin{array}{l}\text { May (3), August (1), } \\
\text { October (16) }\end{array}$ \\
\hline 9 & 56.3 & 14.6 & June (1), October (5) \\
\hline 14 & 93.3 & & \\
\hline 3 & 60.0 & & \\
\hline 9 & 60.0 & 31.7 & $\begin{array}{l}\text { May (3), July (3), } \\
\text { October (7) }\end{array}$ \\
\hline 13 & 86.7 & & \\
\hline
\end{tabular}

genetic analyses, the Mediterranean colony of Almeria intermingled with the Atlantic cluster. Concerning the spatial pattern of variation in morphology, we found a longitudinal geographic gradient in body measurements within the Mediterranean subspecies as a slight increase in body size from east to west Mediterranean subspecies, a biometric pattern previously recognized by other authors (Massa and Lo Valvo 1986, Granadeiro 1993). This pattern is probably related to the complex longitudinal oceanographic subzonation within the Mediterranean basin. Specific marine habitat characteristics of different areas within the Mediterranean, such as differences in sea surface temperature, wind speed, and primary production, probably promoted divergence in body size through local adaptation of populations (Zotier et al. 1999). On the contrary, no spatial pattern was apparent within the Atlantic, although some authors have recently reported slight latitudinal differences from the Canary to Azores Islands (Thibault et al. 1997, Gómez-Díaz et al. 2006).

Morphological measures could be used to reliably assign most birds to the taxon (species or subspecies), provided that the sex of the birds was previously determined, since Cory's Shearwaters show an appreciable sexual size dimorphism. However, assignment tests based on morphological data failed to identify the geographic origin of Cory's Shearwaters at their breeding colony. Recent studies on the seabird genus Puffinus sp. showed that only species with widespread distributions would exhibit noticeable geographic variation in their morphometrics (Bull et al. 2005). Consequently, data supplementary to the more traditional biometric approach, such as isotopes, trace elements, or genetic markers, are probably necessary for the geographic assignment of most seabird species.

\section{Stable isotopes and trace elements}

Stable isotopes signatures separated most breeding colonies according to their geographic distributions, although to a lesser extent than the biometric and genetic structuring. The influence of Atlantic waters entering the Mediterranean would explain the isotopic similarity of the three most western Mediterranean colonies (i.e., Murcia, Almeria, and Chafarinas) to those of the Atlantic (Fig. 2C). In contrast, although showing the largest distances compared to any other approach, no geographical structure among breeding colonies was evident for trace elements.

In the present study, both $\delta^{15} \mathrm{~N}$ and $\delta^{13} \mathrm{C}$ values of the first primary feather varied across the breeding range of Cory's Shearwaters and differed from those for the Cape Verde Shearwater. Since the first primary feather is grown at the end of the breeding period, we can expect the isotopic signatures of this feather to reflect those from the prey consumed around the breeding area. However, evidence of biogeographic patterns of stable isotope values in marine ecosystems is still scarce, and several studies showed large differences in the degree of geographic variation of isotope biomarkers, depending on the spatial scale of analysis (Chamberlain et al. 1997, Marra et al. 1998, Wassenaar and Hobson 2001, Wunder et al. 2005). Whereas most studies successfully applied $\mathrm{C}$ and $\mathrm{N}$ isotope ratios to discern geographically distinct subspecies, most failed to discriminate among geographic origins at regional and local scales (see Hobson 1999 for a complete review). In line with results found in other studies in both terrestrial and marine ecosystems, we found feather isotope values of $\mathrm{C}$ and $\mathrm{N}$ to vary by latitude and longitude, respectively. However, the strength of these patterns depended on the geographic scale considered (see Figs. 3, 4). The geographic break in isotope values between Atlantic and Mediterranean regions effectively separated the two subspecies. However, isotope geographical gradients within each region, although eventually significant, were too weak to reliably assign the origin of birds at local scales. This inaccuracy probably resulted from variance associated with isotope values at a single location, or from similar isotopic baselines values at different areas (Royle and Rubenstein 2004). Alternatively, similarities in isotopic values among neighboring colonies may simply result from birds sharing the same foraging areas. During the chick-rearing period, when the first primary feather is grown, shearwaters use a flexible foraging strategy, i.e., they forage close to the colonies, mainly to feed the chicks, but far offshore for self feeding (Granadeiro et al. 1998, Cherel et al. 2005), potentially overlapping with shearwaters breeding in other islands.

However, sharing foraging areas of neighboring islands cannot solely explain the lack of spatial resolution of isotopic values, because this should then hold true for the 

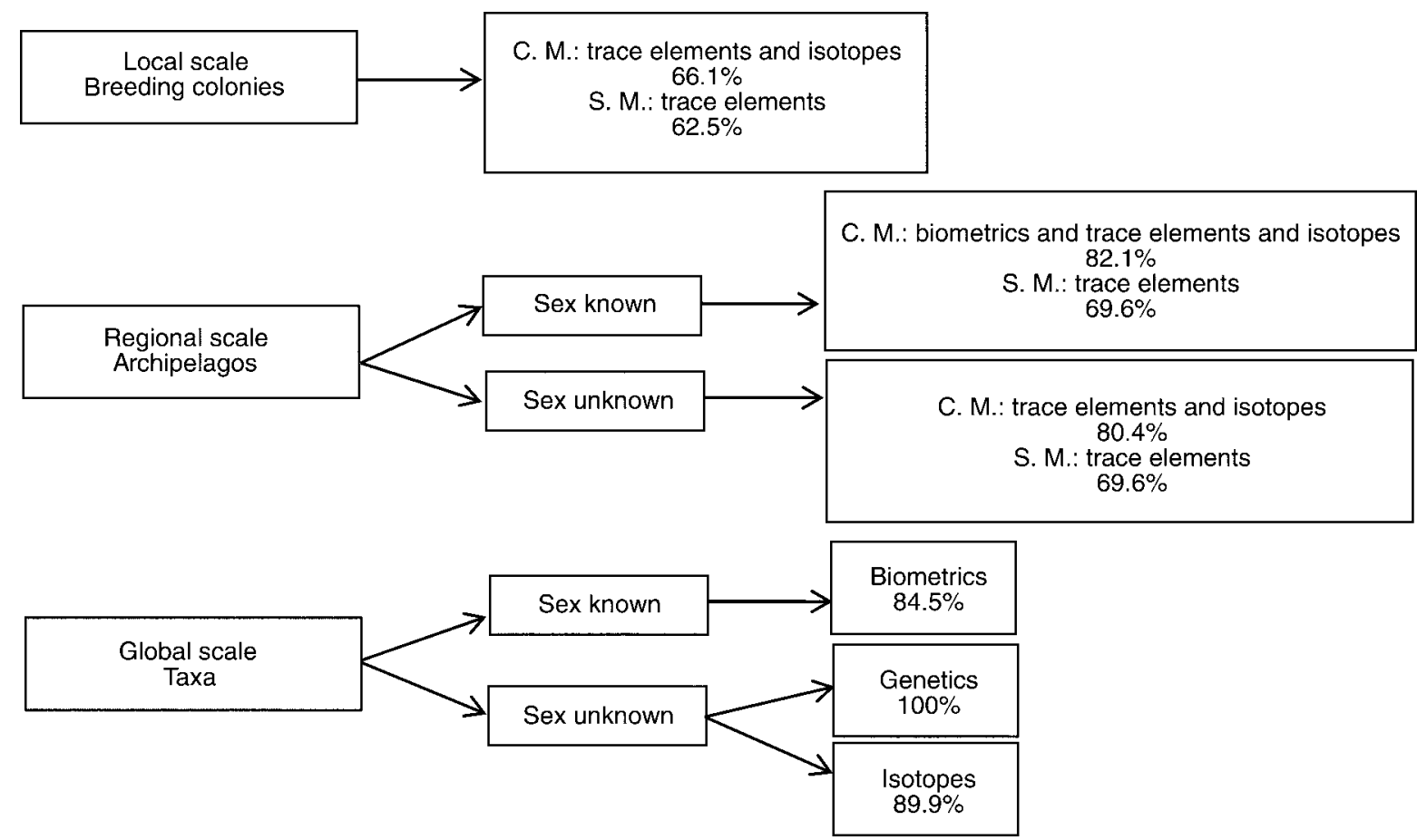

FIG. 5. Decision tree showing the recommended approach for the geographic assignment of seabird specimens, depending on the spatial scale of resolution desired and the possibility to determine the gender. Decisions have been made based on rates of correct assignment for test data validations. "C. M." denotes the combined model, i.e., when using several markers, and "S. M." denotes the single model, i.e., when using a single marker.

trace element composition of these feathers. Instead, we found specific trace element profiles associated with each breeding location, but in contrast with stable isotopes, we could not detect latitudinal or longitudinal patterns in feather composition (Fig. 2D). Differences in elemental composition of feathers allowed us to discriminate the origin of birds at different geographic scales, that is, from specific breeding colonies (77.5\% of correct assignments), considering archipelagos $(75.2 \%)$, and identifying taxa (89.9\%). However, correct classification at the colony and archipelago levels decreased to $62.5 \%$ and $69.6 \%$, respectively, when we classified $20 \%$ of the samples randomly excluded from the analyses prior to building the discriminant model. The model performed even worse for classifying an independent set of samples collected in previous years and analyzed separately, dropping to $23.5 \%$ and $41.2 \%$ correct classification. These results illustrate the limitations of these models to classify samples other than those used to build them. The drop in the classification rates of samples collected in previous years may reflect interannual variability in trace element composition. In addition, the lack of spatial gradients in trace elements composition across the breeding range of the species underlies the need for a geographically widespread sampling design. Sampling discontinuities and missing populations would lead to inaccuracies in the assignment of individuals to specific locations. In addition, missclassifications in the validation methods among, i.e., Cape Verde and Canary/Azores missassigned birds (Table 2), would be explained because baseline levels of the three areas are similar. In this case, population trees for any intrinsic marker (Fig. 2) can help us to infer whether the most likely reason for the missassignments is a close similarity among colonies. Still, trace element composition was the intrinsic marker showing the best assignment rates, suggesting that such composition strongly depends upon the microgeographical location of the breeding site. This probably reflects the importance of local conditions and the similarity in foraging areas of birds breeding in the same colony (Szép et al. 2003), although local atmospheric deposition on feathers might also explain these differences to some extent (Breitburg and Riedel 2005).

The combination of several methods enhanced the reliability of the classificatory method both across the different spatial scales $(86.0 \%, 90.7 \%$, and $100.0 \%$, from colony to taxon level), and for all validation methods (e.g., at the archipelago level, $82.1 \%, 94.1 \%$, and $79.8 \%$ for independent data, independent analysis, and jackknife cross-validation, respectively). The benefits of using multiple intrinsic markers has been demonstrated previously (Royle and Rubenstein 2004), and our results highlight that a combined approach should be used when possible.

\section{Bycatch birds}

The preliminary application of the discriminatory model on Cory's Shearwaters caught by Mediterranean 


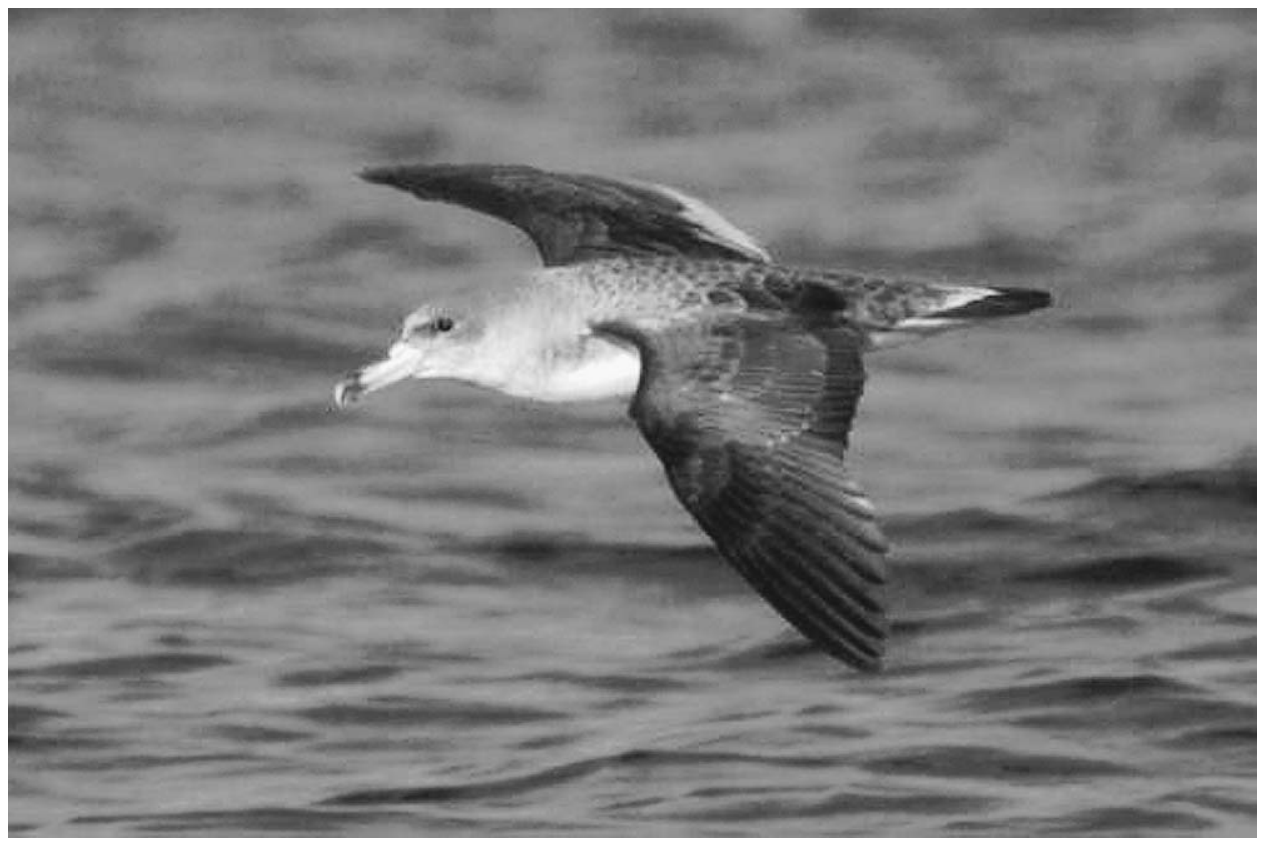

Plate 1. Cory's Shearwater, Calonectris diomedea diomedea, taken off the coast of southeastern France, April 2006. Photo credit: J. González-Solís.

longliners identified three source breeding sites in the Mediterranean (Menorca, Crete, and Ibiza islands) and one from the Atlantic (Graciosa Island). Ancillary information on the capture date, location, and numbers of dead birds recovered may help to contrast model predictions and to test ecological hypotheses. Interestingly, both Menorca and Ibiza breeding colonies are within the operating area of Catalonian longliners and represent major breeding colonies for the species in the central Mediterranean (Thibault et al. 1997). Furthermore, most of the birds assigned to Crete were caught out of the breeding period (86.0\%), either during the prelaying period (i.e., April and May) or during the postnuptial migration (i.e., October and November), when birds have to cross the operating area of the Catalonian longliners returning from or going to the wintering grounds in the subSaharan coast (Ristow et al. 2000). Finally, although we could expect all individuals to belong to the Mediterranean subspecies, we cannot completely rule out the Atlantic identity of some specimens, since there is evidence of Atlantic Cory's Shearwaters entering the Mediterranean (Lo Valvo and Massa 1988, Sánchez 1997, Thibault and Bretagnolle 1998, Martínez-Abraín et al. 2002). However, those birds were caught in May and August, within the breeding period of the species, and their biometric measurements do not support their Atlantic identity. As mentioned above, ghost populations resulting from incomplete sampling designs would force the model to assign birds elsewhere. In the present study, although the sampling design covered almost the whole breeding range of the species, a few central Mediterranean populations were missed (mainly Zembra, Malta, Corsica, and Sardinia), which may partly explain assignment errors when applying the model.

\section{Conclusions}

Overall, the effectiveness of the four types of biomarkers evaluated, i.e., genetic, morphometric, trace element, and isotopic traces for the geographic assignment of Cory's Shearwaters, varied with the spatial scale of analysis. The application of intrinsic markers depends on there being enough differences among potential source breeding colonies to unequivocally assign individuals to their source. Which method should be applied also depends on the level of spatial resolution desired and the ancillary information we have, such as the sex of the bird (Fig. 5). Whereas the identification of Atlantic and Mediterranean Cory's Shearwater subspecies and the Cape Verde species was successfully achieved for all four types of markers, large differences arose in the correct assignment of the breeding colonies among these methods. Both morphometric and genetic approaches appeared ineffective at discriminating among geographically close breeding sites. With respect to biogeochemical markers, stable isotopes showed some latitudinal and longitudinal trends, but the predictive power of these trends to classify individuals among putative sources was rather weak. In contrast, trace elements appeared more sensitive to microgeographical differences than were stable isotopes, and allowed the best rate of correct assignment of feathers at local scales. However, trace elements did not show geographical gradients, and thus ghost populations, the result of incomplete 
sampling designs, can force the model to erroneously assign birds to very distant colonies rather than identifying their true origin. Adding isotopes to models based on trace elements did not enhance the rate of successful assignment of the training data, but substantially improved classification rates of the independent data sets, increasing the robustness and accuracy at all the spatial scales of analysis. Determining the origin of dead individuals is important for any attempt to assess the potential impact of human activities, such as oil spills, long-line fishing, or offshore wind farms, responsible for an increase in seabird mortality at sea. Our study shows that it is feasible to use biogeochemical markers of seabird feathers, such as trace elements and stable isotopes, to identify the impact of such activities on specific breeding seabird populations at a local scale.

\section{ACKNOWLedgments}

We thank all the people who collected samples for us; F. Zino, M. Detrakis, E. Vidal, J. Legrand, K. Bourgeois, M. Lo Valvo, U. Foscola, N. Bacetti, and R. Notari. We also thank J. Bried, P. Faria, P. Domínguez, P. Tavares, A. Texeira, A. Martínez, J. C. Nevado, M. Paracuellos, J. P. Enciso, G. González, M. García, J. M. Igual, M. G. Forero, M. McMinn, J. Mayol, J. Amengual, M. Mayol, C. Santana, R. Escandell, R.Triay, P. Lopez., L. F. López-Jurado; all of them helped us with the field work at different stages and in several ways. We thank all people and all institutions who provided us means and support, especially X. Ruiz, C. Sanpera, the Gobierno de Canarias, the Cabildo Insular of Gran Canaria and Lanzarote, and the association "Amigos de las pardelas." We thank all people and all longliners who provided us with bycatch specimens: V. Pedrocchi, M. Diaz, N. Zaragoza, "La Maca III," "Hnos Galindo," "Cona," "Som i Serem," and "Pare Joan." Special thanks to M. A. Peinado and all the MAP Lab team for their personal and technical support with molecular analyses. Thanks to J. Navarro, J. L. Roscales, and R. Ramos for their help with the biochemical analyses. M. G. Forero and $\mathrm{K}$. Hobson kindly agreed that we could include their data on stable isotope analyses from Cory's Shearwaters breeding at Chafarinas Island. The comments of two anonymous referees and V. L. Friesen greatly improved the first version of the manuscript. Finally, we particularly thank V. Neves, P. Calabuig, M. Cerdà and family, J. Rodríguez, R. Mayor, E. Vendrell, L. Llorens, and J. Scopel for offering us their personal and professional support. E. Gómez-Díaz was supported by a postgraduate grant from the Generalitat de Catalunya, and J. González-Solís was supported by the Program Ramon y Cajal funded by the Ministerio de Educacion y Ciencia (MEyC) and Fondos FEDER. Financial support was provided by the projects REN2002-01164 and CGL2006-01315/BOS from the MEyC, by project 2001SGR-00091 from the Generalitat de Catalunya, by a Fundacion Banco Bilbao Vizcaya Argentaria project and the Port-Cros National Park LIFE programme LIFE03NAT/F000105.

\section{Literature Cited}

Arribas, R., S. Tòrtola, J. Welsh, M. McClelland, and M. A. Peinado. 1997. Arbitrarily primed PCR and RAPDs. Pages 47-53 in M. R. Micheli and R. Bova, editors. Fingerprinting methods based on arbitrarily primed PCR. Springer, Berlin, Germany.

Austin, J. J., R. W. White, and J. R. Ovenden. 1994. Population-genetic structure of a philopatric, colonially nesting seabird, the Short-tailed Shearwater (Puffinus tenuirostris). Auk 111:70-79.
Bassam, B. J., G. Caetano-Anolles, and P. M. Gresshoff. 1991. Fast and sensitive silver staining of DNA in polyacrylamide gels. Analytical Biochemistry 196:80-83.

Becker, P. H., J. González-Solís, B. Behrends, and J. P. Croxall. 2002. Feather mercury levels in seabirds at South Georgia: influence of trophic position, sex and age. Marine Ecology Progress Series 243:261-269.

Beckers, J. M., P. Brasseur, and J. C. J. Nihoul. 1997. Circulation of the western Mediterranean: from global to regional scales. Deep-Sea Research II 44:531-549.

Boersma, P. D., D. L. Stokes, and I. J. Strange. 2002. Applying ecology to conservation: tracking breeding penguins at New Island South reserve, Falkland Islands. Aquatic Conservation: Marine and Freshwater Ecosystems 12:63-74.

Breitburg, D. L., and G. F. Riedel. 2005. Multiple stressors in marine systems. Pages 167-184 in E. A. Norse and L. B. Crowder, editors. Marine conservation biology. Island Press, Washington, D.C., USA.

Bried, J., and P. Jouventin. 2002. Site and mate choice in seabirds: an evolutionary approach. Pages $263-305$ in E. A. Schreiber and J. Burger, editors. Biology of marine birds. CRC, Boca Raton, Florida, USA.

Brothers, N. P., J. Cooper, and S. Lokkeborg. 1999. The incidental catch of seabirds by longline fisheries: worldwide review and technical guidelines for mitigation. Food and Agriculture Organization of the United Nations, Rome, Italy.

Browne, S. J., J. A. Clark, and W. J. Peach. 2004. The utility of national ring recoveries for identifying the effects of an exceptional mortality event amongst seabirds. Ringing and Migration 22:35-42.

Bruford, M. W., O. Hanotte, J. F. Y. Brookfield, and T. Burke. 1998. Multilocus and single-locus DNA fingerprinting. Pages 225-269 in A. R. Hoelzel, editor. Molecular genetic analysis of populations: a practical approach. IRL Press at Oxford University Press, New York, New York, USA.

Bull, L. S., B. D. Bell, and S. Pledger. 2005. Patterns of size variation in the shearwater genus Puffinus. Marine Ornithology 33:27-39.

Cadiou, B., E. Cam, M. Fortin, J.-Y. Monnat, G. Gélinaud, J. Cabelguen, and A. Le Roch. 2003. Impact de la marée noire de l'Erika sur les oiseaux marins migrateurs: détermination de l'origine et de la structure des populations par la biométrie. Rapport Bretagne Vivante-SEPNB, DIREN Bretagne, France.

Cadiou, B., L. Riffaut, K. D. McCoy, J. Cabelguen, M. Fortin, G. Gelinaud, A. Le Roch, C. Tirard, and T. Boulinier. 2004. Ecological impact of the "Erika" oil spill: determination of the geographic origin of the affected common guillemots. Aquatic Living Resources 17:369-77.

Carneiro da Silva, M., and J. P. Granadeiro. 1999. Genetic variability and isolation of Cory's Shearwater colonies in the northeast Atlantic. Condor 101:174-179.

Carter, H. R. 2003. Oil and California's seabirds: an overview. Marine Ornithology 31:1-7.

Chamberlain, C. P., J. D. Blum, R. T. Holmes, X. Feng, T. W. Sherry, and G. R. Graves. 1997. The use of isotope tracers for identifying populations of migratory birds. Oecologia 109:132-141.

Cherel, Y., K. A. Hobson, and H. Weimerskirch. 2000. Using stable-isotope analysis of feathers to distinguish moulting and breeding origins of seabirds. Oecologia 122:155-162.

Cherel, Y., K. A. Hobson, and H. Weimerskirch. 2005. Using stable isotopes to study resource acquisition and allocation in procellariiform seabirds. Oecologia 145:533-540.

Cherel, Y., R. A. Phillips, K. A. Hobson, and R. McGill. 2006. Stable isotope evidence of diverse species-specific and individual wintering strategies in seabirds. Biology Letters 2:301-303

Edwards, S. V., M. C. Silva, T. M. Burg, V. L. Friesen, and K. I. Warheit. 2001. Molecular genetic markers in the 
analysis of seabird bycatch populations. Pages 115-140 in E. F. Melvin and J. K. Parrish, editors. Seabird bycatch: trends, roadblocks and solutions. University of Alaska Sea Grant, Anchorage, Alaska, USA.

Excoffier, L., P. E. Smouse, and J. M. Quattro. 1992. Analysis of molecular variance inferred from metric distances among DNA haplotypes: application to human mitochondrial DNA restriction data. Genetics 131:479-491.

Forero, M. G., J. González-Solís, K. A. Hobson, J. A. Donázar, M. Bertellotti, G. Blanco, and G. R. Bortolotti. 2005. Stable isotopes reveal trophic segregation by sex and age in the southern giant petrel in two different food webs. Marine Ecology Progress Series 296:107-113.

Fridolfsson, A.-K., and H. Ellegren. 1999. A simple and universal method for molecular sexing of non-ratite birds. Journal of Avian Biology 30:116-121.

Friesen, V. L., T. M. Burg, and K. D. McCoy. 2007. Mechanisms of population differentiation in seabirds. Molecular Ecology, in press.

García, L., C. Viada, R. Moreno-Opo, C. Carboneres, A. Alcalde, and F. González. 2003. Impacto de la marea negra del Prestige sobre las aves marinas. SEO/BirdLife, Madrid, Spain.

Garthe, S., and O. Hüppop. 2004. Scaling possible adverse effects of marine wind farms on seabirds: developing and applying a vulnerability index. Journal of Applied Ecology 41:724-734.

Gómez-Díaz, E., J. González-Solís, M. A. Peinado, and R. D. M. Page. 2006. Phylogeography of Calonectris shearwaters using molecular and morphometric data. Molecular Phylogenetics and Evolution 41:322-332.

González-Solís, J., J. P. Croxall, D. Oro, and X. Ruiz. 2007. Transequatorial migration and mixing in the wintering areas in a pelagic seabird. Frontiers in Ecology and the Environment, in press.

Granadeiro, J. P. 1993. Variation in measurements of Cory's shearwaters between populations and sexing by discriminant analysis. Ringing and Migration 14:103-112.

Granadeiro, J. P., M. Nunes, M. P. Silva, and R. W. Furness. 1998. Flexible foraging strategy of Cory's shearwater, Calonectris diomedea, during the chick-rearing period. Animal Behaviour 56:1169-1176.

Heidrich, P., D. Ristow, and M. Wink. 1996. Molekulare differenzierung von gelb- und schwarzschnabelsturmtauchern (Calonectris diomedea, Puffinus puffinus, P. yelkouan) und großmöwen des silbermöwenkomplexes (Larus argentatus, L. fuscus, L. cachinnans). Journal für Ornithologie 137: 281-294.

Hobson, K. A. 1999. Tracing origins and migration of wildlife using stable isotopes: a review. Oecologia 120:314-326.

Hobson, K. A. 2005. Using stable isotopes to trace longdistance dispersal in birds and other taxa. Diversity and Distributions 11:157-64.

Hüppop, O., J. Dierschke, K.-M. Exo, E. Fredrich, and R. Hill. 2006. Bird migration studies and potential collision risk with offshore wind turbines. Ibis 148:90-109.

Kelly, J. F., K. C. Ruegg, and T. B. Smith. 2005. Combining isotopic and genetic markers to identify breeding origins of migrant birds. Ecological Applications 15:1487-1494.

Lebreton, J. D., and J. Clobert. 1991. Bird population dynamics, managements and conservation: the role of mathematical modelling. Pages $105-125$ in C. M. Perrins, J. D. Lebreton, and G. J. M. Hirons, editors. Bird population studies: their relevance to conservation and management. Oxford University Press, Oxford, UK.

Lewison, R. L., D. C. Nel, F. Taylor, J. P. Croxall, and K. S. Rivera. 2005. Thinking big - taking a large-scale approach to seabird bycatch. Marine Ornithology 33:1-5.

Lo Valvo, M., and B. Massa. 1988. Considerations on a specimen of Cory's shearwater ringed at Selvagem Grande and recovered in the central Mediterranean. Bocagiana 124: $1-5$.

Lovette, I. J., S. M. Clegg, and T. B. Smith. 2004. Limited utility of mtDNA markers for determining connectivity among breeding and overwintering locations in three Neotropical migrant birds. Conservation Biology 18:156-66.

Lynch, M., and O. E. B. G. Milligan. 1994. Analysis of population genetic structure with RAPD markers. Molecular Ecology 3:91-99.

Manel, S., O. E. Gaggiotti, and R. S. Waples. 2005. Assignment methods: matching biological questions with appropriate techniques. Trends in Ecology and Evolution 20:136-142.

Marra, P. P., K. A. Hobson, and R. T. Holmes. 1998. Linking winter and summer events in a migratory bird by using stable-carbon isotopes. Science 282:1884-1886.

Martínez-Abraín, A., A. Sanchez, and D. Oro. 2002. Atlantic Cory's shearwater breeding in a colony of Mediterranean Cory's shearwaters. Waterbirds 25:221-224.

Massa, B., and M. Lo Valvo. 1986. Biometrical and biological considerations on the Cory's shearwater Calonectris diomedea. NATO ASI Series G 12:293-313.

Mehl, K. R., R. T. Alisauskas, K. A. Hobson, and D. K. Kellet. 2004. To winter east or west? Heterogeneity in winter site philopatry in a central Arctic population of King Eiders. Condor 106:241-251.

Monteiro, L. R., and R. W. Furness. 1996. Moult of Cory's shearwater during the breeding season. Condor 98:216-221.

Nybom, H. 2004. Comparison of different nuclear DNA markers for estimating intraspecific genetic diversity in plants. Molecular Ecology 13:1143-1155.

Paetkau, D., W. Calvert, I. Stirling, and C. Strobeck. 1995. Microsatellite analysis of population structure in Canadian polar bears. Molecular Ecology 4:347-354.

Pearce, J. M. 2006. Minding the gap: frequency of indels in mtDNA control region sequence data and influence on population genetic analyses. Molecular Ecology 15:333-341.

Pérez, T., J. Albornoz, and A. Domínguez. 1998. An evaluation of RAPD fragment reproducibility and nature. Molecular Ecology 7:1347-1357.

Quillfeldt, P., R. McGill, and R. W. Furness. 2005. Diet and foraging areas of Southern Ocean seabirds and their prey inferred from stable isotopes: a review and case study of the Wilson's storm-petrel. Marine Ecology Progress Series 295: 295-304.

Rabouam, C., V. Bretagnolle, Y. Bigot, and G. Periquet. 2000. Genetic relationships of Cory's shearwater: parentage, mating assortment, and geographic differentiation revealed by DNA fingerprinting. Auk 117:651-662.

Randi, E., F. Spina, and B. Massa. 1989. Genetic variability in Cory's shearwater (Calonectris diomedea). Auk 106:411-417.

Riffaut, L., K. D. McCoy, C. Tirard, V. L. Friesen, and T. Boulinier. 2005. Population genetics of the common guillemot Uria aalge in the North Atlantic: geographic impact of oil spills. Marine Ecology Progress Series 291:263-293.

Ristow, D., P. Berthold, D. Hashmi, and U. Querner. 2000. Satellite tracking of Cory's Shearwater migration. Condor 102:696-699.

Rohlf, F. J. 1997. NTSYS-pc numerical taxonomy and multivariate analysis system. Exeter Software, Setauket, New York, USA.

Rousset, F. 1997. Genetic differentiation and estimation of gene flow from $F$-statistics under isolation by distance. Genetics 145:1219-1228.

Royle, J. A., and D. R. Rubenstein. 2004. The role of species abundance in determining breeding origins of migratory birds with stable isotopes. Ecological Applications 14:17801788.

Sánchez, A. 1997. La Pardela cenicienta (Calonectris diomedea) en las islas Columbretes: biología y conservación. Thesis. Universitat de València, Valencia, Spain. 
Schneider, S., D. Roessli, and L. Excoffier. 2000. Arlequin a software for population genetics data analysis. Genetics and Biometry Laboratory, Department of Anthropology, University of Genoa, Genoa, Italy.

SPSS. 2003. SPSS version 12.0. SPSS, Chicago, Illinois, USA.

Stratford, J. M., and K. E. Partridge. 1996. An analysis of biometrics of oil-contaminated common guillemots Uria aalge in South-West Britain, 1980-1994. Seabird 18:38-43.

Szép, T., A. P. Moller, J. Vallner, B. Kovács, and D. Norman. 2003. Use of trace elements in feathers of sand martin Riparia riparia for identifying moulting areas. Journal of Avian Biology 34:307-320.

Thibault, J. C., and V. Bretagnolle. 1998. A Mediterranean breeding colony of Cory's shearwater Calonectris diomedea in which individuals show behavioural and biometric characters of the Atlantic subspecies. Ibis 140:253-258.

Thibault, J. C., V. Bretagnolle, and C. Rabouam. 1997. Cory's shearwater. BWP Update. Oxford University Press, Oxford, UK.
Wassenaar, L. I., and K. A. Hobson. 2001. A stable-isotope approach to delineate geographical catchment areas of avian migration monitoring stations in North America. Environmental Science and Technology 35:1845-1850.

Webster, M. S., P. P. Marra, S. M. Haig, S. Bensch, and R. T. Holmes. 2002. Links between worlds: unravelling migratory connectivity. Trends in Ecology and Evolution 17:76-83.

Wink, M., P. Heidrich, and D. Ristow. 1993. Genetic evidence for speciation of the Manx shearwater Puffinus puffinus and Mediterranean shearwater Puffinus yelkouan. Die Vogelwarte 114:226-232.

Wunder, M. B., C. L. Kester, F. L. Knopf, and R. O. Rye. 2005. A test of geographic assignment using isotope tracers in feathers of known origin. Oecologia 144:607-617.

Zotier, R., V. Bretagnolle, and J. C. Thibault. 1999. Biogeography of the marine birds of a confined sea, the Mediterranean. Journal of Biogeography 26:297-313.

\section{APPENDIX A} A1).

Geographic location of Cory's and Cape Verde Shearwaters and sample sizes for each analysis (Ecological Archives A017-058-

\section{APPENDIX B}

Morphological measurements for all Calonectris breeding colonies included in the biometric analysis (Ecological Archives A017058-A2).

\section{APPENDIX C}

Mean and standard deviation of stable isotopes signatures and trace elements concentrations of Cory's Shearwater and the Cape Verde Shearwater breeding colonies (Ecological Archives A017-058-A3).

\section{APPENDIX D}

Regression models on the latitudinal and longitudinal gradients in stable isotopes signatures, trace elements concentrations, and morphometric measurements (Ecological Archives A017-058-A4). 